\title{
雑草群落の生態学的研究
}

\author{
千葉大学交理学部 沼 田真
}

\section{Makoto Numata: Ecological Studies on Weed Communities}

杂隹草群落の生態学的研究について, 私は今までに数回 秎説と問題提起を行なった。すなわち, 沼田 (1954) ${ }^{1)}$, 沼田・荒井 (1954) ${ }^{2)}$, 沼田 $(1956,58)^{3)}$, 沼田 $(1958)^{4)}$, 沼田 $(1961)^{5)}$ などにおいて, 雑草および雑草群落を生態 学的にはどのように报からべきであるかについてのべた。 ここでは主に最近の研究を展望しつつ, あわせて問題の ありかをざってみたい。

\section{1. 耕地生態学ないし農業生態学}

雑草生態学 (weed ecology) について展望を与えよ うとするのぶ本稿の目的であるが, それは応用生態学の 中で，まださほど確固たる地位をしめているものとは思 われない。植物系の応用生態学の中では, 森林生態学 (forest ecology ないし silvics) の伝統が最も古く、つ いで草地生態学 (grassland ecology, range ecology, pasture ecology など）がその基礎をかためつつある。 われわれの生活に最も古くから最も密接な関倸をもって いたはずの (農) 耕地の生態学 (agricultural ecology [agroecology], crop ecology, weed ecology など) は，生態学としての骨格を与えられるのが最もおそかっ た。わが国でもこの方面の体系的な研究はきわめて少な い。そこで, まずはじめに耕地生態学ないし農業生態学 こついて展望したのちに雑草生態学へうつりたいと思 50

わが国で翻訳のでたAzzl(1956，野口訳 19586))よれに ば, “農業生態学は，作物の発去ならびに収量に関し，量 的(収穫高), 質的(生産物の品質), および遺伝的 (種物 の性罂）の見地から，環境すなわち気候および土壤等の 物理的特性を研究するものである”とし，またべつなと ころでは, “農業生態学は, 耕種学, 経済学ならびに遺伝 学的立場から，多くの農業に関する問題の解決に必要な 気象的環境を数的にあらわすものである”とものべてい る。そしてこの “農業生態学は, 独自の活動の場面なら びに範囲をもって農業科学の分野に特殊な位置をしめて いることは明らかで, 自然科学者の取扱っている一般生 態学とは原理, 研究方法, 構成などの点で全然異なって いる”という。このように農業生態学を環境学的に規定 し, かつ收量の経済学的側面とも結びつけて, その独自 性をうたおうとする $\mathrm{Azz}$ ：の立場は今日一般に容認され
るとは思われない。先に私は, 一般生態学と応用生態学 との関係を論じたが(沼田 1954)7), 農業生態学は農業と 一般生態学のかけ橋という位置をしかるものであり，方 法論においては全く同一の生態学的基盤にたち, 収舅の 経済性といった社会科学的性格を与えることは, 生態学 の立場に混乱を与えるものであらう。

この点に関して KLAGES(1942) $)^{8}$ は，作物生態学(crop ecology) は, 作物とその生理学的環境との関係を明ら かにするものであって，作物の生産と分布に及ぼす経済 的原因はとりあげないのに対し，作物生態地理学 (ecological crop geography) は，作物の生産と分布に及ぼ す生理的環境（physiological environment）のみな ず，経済的・政治的・歷史的・技術的・社会的要因など を含めた社会的環境 (social environment) をとりあげ るのであるとしている。つまり KLAGESの場合は，彼な りに，自然科学としての作物生態学さ，社会科学にもま たがった農学的な作物生態地理学を区別しているわけで ある。

ところが PAPADAKIS (1954) 9) の作物生態学になる々 KLAGES のそれ(作物生態地理学と区別された)とし下, 社会経済的原因を排除し，まず一般原理を，植生とその 遷移, 個生態と群生態といった形での心, 要因としては 気候・土塁のほかに群落学的 (phytosocial) な要因を重 視している。彼の場合は, 農業姕理学になってもこの方 針はかわっていない（PAPADAKIS 1952, 沼田・山本訳 1962 ${ }^{10)}$; PAPADAKIS 196011)), その意味で, PAPADAK!S の仕事壮, 生態学のプリンシプルの農学への適用として 極めて興味ふかい。彼の農業地理学 (1952) には, 副題 として, “気候, 成長率と生育のリズム, 植生, 土壌, 作 物, 農業地域”とあるが, これが彼の方針をよく示して いるといえよう。

同じように生態学的プリンシプルの農学への適用を企 図した仕事としては，たとえばすでに一般生態学者とし ても十分高く評価されている KNAPP (1949 ${ }^{12)}$; 1954，沼 田真·吉田治訳1962) ${ }^{13)}$, TüXeN $\left.{ }^{14}\right)$, AlCHINGER ${ }^{15)}$, ELLENBERA (1952)16) ら中欧系の学者のものがある。彼らの出 事を大きく概括すると， EILLNBERG の標題にあるよう に指標 (Zeiger) という考えにつきる。雑草群落を構成 する種の特性を利用して農耕地の立地条件を判定し, 適 
地適作の指標とし, 収量をも推定するといった考え方で ある。雑草としての種の特性を大きくとりあげた生態学 者の研究には, HaMel et DANSEREAU (1949) ${ }^{17}$ )のごとき ものも市る。

また昰くアフリカにいて農業や林業の基礎としての生 態学的研究をつゔけてきた PHILLIPS (1959) ${ }^{18)}$ の農業生 態学は, ガーナのエンクルマ首相の序文にもあるように “生態学——私は生態学を, あらゆる生命形態の, それ ら相互の, またその環境亡の相互作用の研究にあると理 解しているのであるが-—は, 農学者のためだけのもの ではない。生態学は農夫, 行政官, 政治家に対しても導 きの光を与えるにちがいない”といった期待のされ方を しているのであるが，彼の書物は自然科学としての農業 生態学を,アフリカにおける植生とその遷移を気候と土 塆にもとづいて理解し, 極相と生物気候区の認識を農業 発展の基礎としょうこしたものである。

わ礼われも, 以上のような生態学出身の人達の行き方 を支持するのであるが, 要するに耕地生態学を技術学な いし経営学的な農学そのものと等置しないで, 臨床 (Klinik) としての農学に対して, 基礎 (Grund)として の一般生態学, そのかけ橋である診断学 (Diagnostik) としての耕地生態学という位置づけをしたい上思う。

\section{2. 雑草生態学}

雑草生驡学は必ずしも耕地生態学ないし農業生態学の みに所属するものではないが, 耕地生態学を一応以上の ように位置づけた上で雑草生態学を展望してみよう。

植物生態学は今日極好て多くの分野を含志汇至ってい るが，これを“個体の生態学と群落の生態学とに大別さ れる”之み，前者は “生理的に取扱う個体生態学”で， 後者は“植物集団の分類・発達之, その数的統計を処理 する植物社会学” であるとする意見 (郡場1953) ${ }^{19}$ ) は今 日でもかなり強い。しかし，生物集団の基本的単位であ る個体も, 生態学では “集団の中の個”として, 具体的 な生活の中での位置づけが考えられているところから， 私性態学を二大別するなら, むしろ集団学（あるいは 社会学 sociology) と群集学 (cenology) とにわけた方 がよい上思う。環境学老べつにわけてもよいが, sociological 西るいは cenological なレベルでの生物の生活 の法則が探究されている以上, 当然, それぞれのレベル での環境がとりあげられているので，少なくとも環境学 二個生態学といった形でのとりあげ方は望ましくない。 以上の見地から雑草生態学を展望してみると, 次のよう になるう。

a. Weed sociology いわゆる桷草の個体群（ある
いは個体）および種についての生態学的研究がこの分野 に属する。雑草の種子とその発芽, 成長, 季節現象, 繁 殖, 生活型など, 種の特性についての, 個生態というよ り種生態の研究がその一部危なす。近藤・笠原 (1936ほ か) $)^{20)}, \operatorname{SALISBURY}(1942)^{21)}, \operatorname{KNAPP}(1954)^{13}$ ), 荒井 (1961)22)などの仕事はこの線にそったものといえよう。 その他, イギリス生態学会のシンポジウム諭集として HARPER (1960) ${ }^{23)}$ の編集した “雑草の生態”は, 雑草の分 類, 進化, 休服, 種子散布, 干渉さ競争, 個生態などに わたって広汎な論議を展開している。これらの研究もほ ぼ weed sociology というべきものである。

このような種生態 (specific or species ecology) か らさらにす寸んで個体群生態 (population ecology) の 研究としては, 自己間引の点からみた雑草の特性, とく に栽培植物とのちがいにふれた (LrSENko 1945) 21) 研究, 密度効果としての $3 / 2$ 乗則（依田1957） ${ }^{25 ） な と ゙ を あ け ゙ る こ ~}$ とができるであろう。すなわち LYSENKO によれば，栽 培植物とは反対に, “野生の植物が過度に密に発芽する と, 自己間引の方法で自分の数孛調整し，それぞれの個 体はたがいに邪魔しあったり圧迫しあったりしないで， 同時に全空間をその種でもって占領してしまう。この空 間にその種の競争相手であるような他の植物がはいるこ とを許さないのである”。とのべている。また，3/2乘則 は同種群落（個体群）の被度が 100\%に達した場合, 重 量 $(\omega)$ と密度 $(\rho)$ の間に $\log \omega=-\frac{3}{2} \log \rho+\operatorname{const} の$ 関係のあることをいう。前記の HARPER (1960)23) のい 5 plant demography（植物員数学—人間の場合の 人口学に相当する) のごときもこれに類するものである う。

b. Weed cenology 一般的な雑草群落 (weed community)の研究として非常に多く行なわれてきたの は, 農耕跡地とか休閑地での雑草群落の発達を扱ったも ので，古くはBRENCHLEY (1920)26) あたりから，その後 継者の WARINGTON (1958) 27) などの著名な仕事がある。 一方，放㲤農耕地の多いアメリカなどではこうした研究 はとくにさかんで, Bonck and Penfound (1945)28), Keever (1954) 29), Rice (1954)30), Penfound and Rice (1957)31), QUARTERMAN (1957)32) などたくさんあり,こ れをとくに一般の二次遷移や立地条件との関連で㘼察し たものに, Pavlychenko (1943)33), Odum (1954) ${ }^{34}$, Evans and Dael (1955)35), Bliss and L!nN (1955) ${ }^{362}$ などがある。Curtis (1959)37)などは，ウィスコンシン 州の “植生誌”に执いて, Weed communities の章を もうけ，一般生態学的見地から要領よく扱っている。フ ランスでよくいわれる果樹園あとの遷移 (GrROT et 
BAILLAUD 1956)ふ38) のごときも同じ系列のものである。 われわれも, 耕地雑草群落の構造と遷移という立場から 烟地(沼田1947) ${ }^{39}$ ), 水田(沼田195240), Numata 195341)),

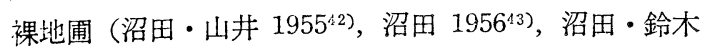

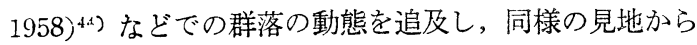
人工草地 (沼田・依田 1957) ${ }^{45}$ ) や, 放牧地 - 採草地(沼 田 196046)，1961 $\mathrm{a}^{47)}, \mathrm{b}^{48)}$ ) について, 二次遷移の実態定 明らかにし, かつ遷移の進行を遷移度によって量的に測 定すること定こころみた。篮原 $(1961)^{49)}$ の最近の研究 にも裸地戋の雑草群落の動態に関寸る研究が多くふくま れている。

ところで農学分野でもっとも要望されているのは, 一 般的な雑草群落ではなく, 耕地, 草地, 林地, 園地 (庭 園，花壇など）などでの crop-weed community とし ての雑草群落の研究である。それも農学分野では weed control，なかでも薬谚防除に主力がそそがれているが， 生態学的研究はそれらの基礎を明らかにしようとしてい る。すなわち薬威防除にしても雑草の弱点をおさえて, 薬剂のもっともきくやり方が必要であるし，またその後 の作物一雑草関係を適確にとらえられね流ならない。そ のための手段しして諸種の群落学的解析が行なわれてい るのである。

われわれ（沼田・荒井 19542)，沼田 19563)）もかっ てそうした見地からの論議文行ない，一方，除草期，播 種谟, 播種密度などによって, 作物対雑草の力関係がか わり，雑草害の出方が非常にことなることを問題にした (沼田・新山 195350)，新山・沼田 1962 $2^{51)}$ )。

古くは CIEMENTs ら(1929) 52)が，植物における競争は 特殊の例をのぞいては struggleではなくて competitionであるとし, それが羡分, 水, 光と温度のうばいあい こいった形のものであること，またそれらが発芽の時期 をこ上にし，あるいは遷移の進行途上での侵大の場合の ような heterochronousな競争と, 一方 synchronous な競争とにわけられることなどをのべた。BLEASDALE $(1956)^{53)}$ Łか MANN and BARNes $(1945 \sim)^{5 !)}$, 笠原 (1961) 55) らの仕事はこらした競争のメカニズムを量的 に定式化しょうとしたものであるし，種間の相互作用を 植物体 (とくに根) から排出される物質をとおして理解 しようとする，いわゆるアレロパチー(Molisch 193756) (Osvald 194957), BoNNer 195058), KNAPP 1954'3) Grümmer 195559), Martin and Rademacher 196060)) つ仕事も一つの顕著な方向である。

以上のほか, Whхте (1940)61) の編した論文集には, 最近も一部で注目されている, いわゆる biological control（主に昆虫による雑草防除）が上りあげられてい
るが，生態学的には興味ふかい。また先にのべた指標植 生の見地にたった ELLENBERG (1952) ${ }^{16)}$ とか, 同じ系列 にたって群落分類の立場からの MYAWAKi (1960；62) の 仕事なども注目してよいであろう。

\section{3. 雑草群落の生態学的研究}

以上のべたような研究動向をたどっている雑草生態学 ではあるが，ここに改めて雑草生態学の体系に琹心をい たし，若干の問題点をひろってみたいと思う。

\section{I. 作物一雑草系の環境}

生態学的環境解析において重要な3つの点については 私は度々のべているが (沼田 1961) ${ }^{63)}$ ，要点は，1)生物 の反态をとおして環境をはかる，2）レベルに応じてきい ている要因を明らかにする，3)環境作用とともに環境形 成 (変革) 作用に注目することである。

たとえば，わが国での気候帯と植生帯との関倸はしば しば諭議されているが，そこでいう植生帯には極相が用 いられており, 雑草群落のように遷移の初期段階のもの が従来いわれている大気候的な区分とどう関係するかは あまり明確ではない。北海道の雑草フロラが本州以南と ちがうことは時々指摘されているが，フロラのちがいの みならず，共通種であっても生育りス゚ムのちが、汇よっ て地域性をつかむことが可能であろう。

さらに環境のレベルを下げて, 中気候的，あるいは小 気候的に, 雑草群落に対する環境作用と, その環境形成 作用を明確にする必要がある。もちろんこれは気候だけ でなく，土壌条件についても，全く同様のことがいえ る。

また生物の反応をとおして環境をはかるという考えは indicator, phytometer, life-form などの方法に通ずる ものであるが, これについては, 彷来農学でよく用いら れた特定の種による指標 (floristic indicator一清水 1960) (1) $^{2}$ よも，一般的には群落を指標とする (vegetational indicator) 方がよく, それも生活型（休眠型, 繁殖型，生育型など）の組みあわせによる群落型による

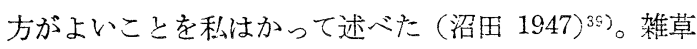
は元来その発生上，環境条件の広い巾に適応したきのな ので，特定の種を指標上するには不向きな面が多いから である。

\section{II. 相互作用 (coaction)}

相互作用は, 種内 (intraspecific) の相互作用二, 種 間 (interspecific) のそれにわけられる。種内相互作用 は個体群 (population) レベルの現象であるが，個体群 の成長法則としての密度効果や種内競争, 雑草個体群成 立過程における自然閯引，自然補充現象通じての種内 
密度調節 ${ }^{44)}$, 分布調節 (分布型や分布様式の変動 ${ }^{44}$, 了 レロパチーのうちでは自家中毒的現象 (autotoxic allelopath y ${ }^{58)}$ が問題になろう。要するに雑草の population dynamics について，まだはっきりしない点がたくさん あるのである。

一方, 共同体レベルの現象としての種間相互作用は, 雑草の実際の生活をとりあげるにあたって最も重要であ るが，種間の結合関係をマクロにとらえる群落分類なり フロラの類似度, それをより細かく統計学的な種間相関 としてあらわし, さらに雑草群落の分散構造を解析する といった方向 (Numata 1961) ${ }^{65}$ ), 地上部の階層構造を いわ汤る生産構造によって解析し（荒井 1956）66），また ひいては地上部, 地下部での競争やすみわけ（沼田1955 67), 沼田・依田 1957) ${ }^{45}$, 除草労力と関連して除草効果 を明確にし(川廷 1962) ${ }^{68}$ ), 場合によっては作物と耕地 雑草との協同的関倸（新山・沼田1962) $)^{51)}$ を明らかにす るなどの方向がある。

ここでとくに注目すべきは，雑草群落の母胎としての 種子集団上芽生え群落であって, 雑草防除には埋土種子 の防除もふくまれているはずであるが，まだ関心はさほ ぞ高くない。雑草群落成立の母胎はいらまでもなく, 埋 土ならびに侵入種子集団である。ところが埋土種子集団 の量は莫大であり，乏の一部がある年の雑草群落の出発 点となる(荒井ら 195969), 沼田ら 196170) 。しかもその 芽生え群落が, 雑草同志または作物対雑草の相互作用を 行ないつつ雑草群落として発達するのである(沼田1961) 5)。とくに種間相互作用においては，ことなった種とい ら歴史的背景をことにした存在が複雑にからみあって, 現在上いう時点での共同体レベルの生活が展開されるの で，種内関係のようにすっきりした解析をゆるさない面 がある。種生態の研究は, こうした面に関しても重要で ある。

\section{III. 作物一雑草系の遷移と進化}

一般に植物群落は, 内部的には種間, 生活型間の相互 作用，外部的には環境との間の相互作用をとおして発達 し，平衡在保ち，崩壊するといったプロセスをくりかえ す。作物一雑草系の遷移においても同様である。このさ いの種の出現交替の順序性, それらの組みあわせ, 遷移

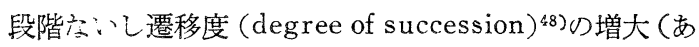
るい法減少）をとらえ，そのメカニズムを明らかにする ことな゙必要である。こうした遷移の要因としては気候・ 土培この間の action（環境作用）， reaction（環境形成 作用), 植物の種閒競争, 病害虫・放牧動物・人間など の㗢きをあげることができる。

耕地においては除草郕の使用が年々さかんになるし，
草地でも火八れ，刚払い，耕起，施肥，追播といった手 段で造成維持が行なわれているし，造成された草地では 放牧・採草が行なわれる。このような条件下での雑草の 侵入・優占の過程は, pyric (火による), anthropeic (人為による), biotic (牛の放牧などによる) succession などとよばれているが，これらを広義の biotic succession として考えてよいであろう。これら biotic factor の種々相と遷移段階を明確につかむことが，雑草群落 考察するにあたっての重要な基礎となるであるう。

また雑草群落成立のメカニズムを考える場合に，人里 植物が問題になる。植物の中で，人のいきがかかった場 所に入りこむ，人間活動とタイアップした植物としての 人里植物 (ruderal plant) が, 雑草 (とくに耕坆, 草 地の雑草）之の共通性老もっている。広義の人里植物に ほ, 狭義の人里植物のほか, 辣地雑草, 帰化植物などを ふくむ。人里植物はオオバコ，クサイなどのようにふみ つけに強く, 再生力大なものであるが, 㷌化植物は, 散 布力, 繁殖力 (種子生産, 発芽率, 残存率, 栄養繁殖), 光発芽の性質などが強く, 初期成長がはやく, 二次遷移 の先駆種 (pioneer species) となる。耕地のごときは 常に立地が翼乱されるため二次遷移の出発点にもどるの で, 先駆種の繁茂の好条件となる。草地では, 過放牧に よって裸地化するのが，ちようど同じような条件をみた し，ふみつけに強以人里植物が繁茂する。こうした諸点 に関しても雑草となるものの種生態学的研究が必要とな る。

またこうした雑草が成立するにあたっては，雑草の生 活をとおしての, crop-weed community の構成員とし ての, 生活型の進化 (沼田 195771)，1958 72)，196073)を 十分考慮しなければならない。従来, 進化といえば系統 的進化が主に考えられているが，生活者としての雑草が もっている対作物あるいは対雑草の種々の特性を理解す る上で，系統的進化とは必ずしも並行しない生態的進化 がとりあげられねばならない。アマ雑草や水田雑草にみ られる，いわゆる作物擬態のごときもその一部をなすを のである。

以上あげたいくつかの問題点に関しては，研究の蓄積 が十分でなく，ある場合にはほとんど分っていない面も あるので, わが国の今後の雑草生態学の進展にあたった は，このような点にも考慮されることが望ましい。

\section{文献}

1) 沼田真：生態学からみた雑草問题. 2,4-D の研究第 3 号 : 3(1954).

2) 沼田真・荒井正雄 : 農業に和ける雑草の諸問題一主に生態学の立 場加ら.生物科学 5(4): 170-177 (1954).

3) 沼田真：雑草の生熊, 自然 4 月号：36-44(1956). 沼田真：生態 学の立場, 古今费院 (1958). 


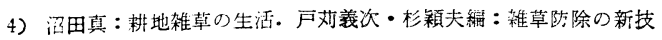
術：13-23，富民社 (1958).

5）垱田真：作物と雑草一生態学の立坫から。これからの農業・園芸 の課通 : 75-77 (1961).

6) Azzi, G.: Agricultural Ecology, London (1956). 野口弥吉 訳：籍栄生態学, 朝會書店 (1959).

7) 泾田真: 応用生熊学のあり方. 生物科学 6 (4) : 188-190(1954),

8) KlaGes, H. W. : Ecological Crop Geography. New York. (1942).

9) Papadakis, J.: Ecologia de los Cultivos I, II, Buenos Aires (1954).

(ii) PaPADakis, J.: Agricultural Geography of the World.

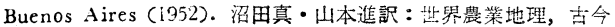
骕语 (1962).

1!) Papadaisis, J.: Geografia Agricola, Barcelona (1960).

1:.) Kxapp, R.: Angewandte Pflanzensoziologie. Stuttgart (1949).

13) KNAPP, R.: Experimentelle Soziologie der höheren Pflanzen. Stuttgart (1954)。沿田真・吉田治訳：实験生態学。 古今然院 (1962)。

14) TÜXEs, R. の編集する Angewandte Pfanzensoziologie や Mitteilungen der Floristisch-soziologischen Arbeitsgemeinschaft 所收の論文。

15) Aichinger, E.の編集する Angewandte Pflanzensoziologie 㟲收の論交。

16) Ellenberg, H.: Landwirtschaftliche Pfanzensoziologie. Bd. I. Unkrautgemeinschaften als Zeiger für Klima und Boden. Stuttgart (1952).

17) Hamel, A. et P. Dansereau: L'aspect ecologique du problème des mauvaises herbes. Bull. Serv. Biogeogr. No. 5 : $1-46$ (1949).

18) Phillips, J.: Agriculture and Ecology in Africa. London (1959).

19）郡场宽：堆物生理生態，養堅堂(1953).

20) 近䒺万太郎・篮原安夫 : 雑草種子の発芽つ研究 (1), 曹学研究 32 : 357-397 (1936) 涪加。

21) SAlisbury, E. J.: The Reproductive Capacity of Plants. London (1942).

22) 荒井正雄 : 水田震作雑草の生態学的研究. 関東東山㴗試研究報告 No. 19 (1961).

23) Harper, J. L. ed.: The Biology of Weeds. Oxford (1960).

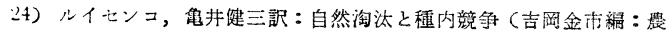
栄生物学々整業技術). 理論社 (1953).

25）供田苏二：群落の密度調節に関する $3 / 2$ 乘則, 第 4 回日本生態学 会䜕演要旨：17 (1957)一沼田真編：植物生態学：181-182, 古今 建院 (1959).

26) Brenchley, W. E.: Weeds of Farm Lands. London (1920).

2i) Warington, K.: Changes in the weed fora on broadbalk permanent wheat field during the period 1930-1955. J. Lcol. 46: 101-113 (1958).

23) Bonck, J. and W. T. PENFondd: Plant succession on abandoned farm land in the vicinity of New Orleans, Louisiana. Amer. Midl. Nat. 33 (2) : 520-529 (1945).

29) KeEver, C.: A new dominant in the first year of old field succession in northwestern South Carolina, Bull. Ecol. Soc. Amer. 35 (3) : 70 (1954).

30) RICE, E.C.: Some factors affecting succession in abandoned farm lands in central Oklahoma. Ecol. 35 (3): 70 (1954).

31) Penfound, W. T. and E. C. RICE: Plant population changes in a native prairie plowed annually over a fiveyear period. Ecol. 38 (1): 148-150 (195i).

32) QUaRTERMan, E.: Early succession on abandoned cropland in the central Basin of Tennessee. Ecol. 38 (2): 300-308 (1957).

23) Pavlychenko, T. K.: Plant succession and weed control Agr. Inst. Rev. March (1943).
34) Odum, E. P.: Organic production and turnover in old field succession on the Savannah River area. Bull. Ecol. Soc. Amer. 35 (3): 71 (1954).

35) Evans, F. C. and E. Dahl: The vegetational structure of an abandoned field in south-eastern Michigan and its relation to environmental factors. Ecol. 36 (4): $685-705$ (1955).

36) BLiss, L. C. and R. M. LinN: Bryophyte communities associated with old field succession in the N. C. Piedmont. Bryologist 58 (2): 120-131 (1955).

37) Curtis, J. T. The Vegetation of Wisconsin. U. Wis. Press (1959).

38) Girot, J. et L. Baillat'D: Observation sur l'evolution des friches de vignes à Besançon. Ann. Sci. Cniviv. Besançon. Bot. 8: 89-100 (1956).

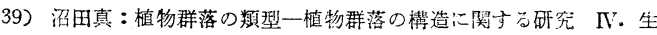
態学研究 $12(1 / 2): 42-48$ (1947).

40) 沼田真: 群落型の季節的変動. 科学 22 (4) : 152 (1952)。

41) Numata, M.: The time series analysis of seasonal variation of vegetation types. 千大交理紀要 1 (3)：194-202 (1953).

42) 沼田真・ 山井広 : 雑草群落の形成過程一第二次菤移の初期段階の 解析 (I). 日生態会報 4 (4): 166-171 (1955).

43) 沼田真：同 (II), 日生態会報 $\mathbf{6}(2): 62-66,6(3): 89-93(1956)$,

44）沼田真・鈴木㤵祐：植物群落の形成過程に関与る实験( I ) 一二论 嘕移の知期段階の解析(III). 日生態会誌 8 (2) : 68-75 (1958).

45) 沼田真・依田港二：人工草地の群落構造と透移, I . 日草地研会 誌 $3(1 / 2)$ ：4-11 (1957).

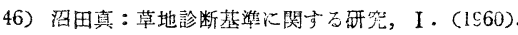

47) 沼田真: 同, II.(1961)

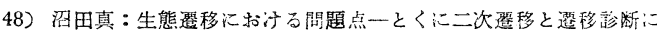
ついて. 生物科学 13 (4): 146-152 (1961).

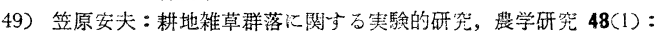
1-32, (3) : 129-178 (1961).

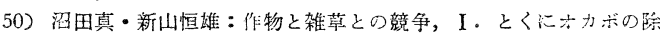
草期汇ついて。植物生態会報 3: 8-13 (1953)。

51）新山恒堆・沼田真：作物と雑草との競争，II。 オカボの播種期と 雑草害の関係。日生態会報 12 (3): 94-100 (1962).

52) Clements, F. E., J. E. Weaver, and H. C. Hasson: Plant Competition. An Analysis of Community Functions. Carnegie Inst. Wash. (1929).

53) Bleasdale, J. K. A.: Interspecific competition in higher plants. Nature $178: 150-151$ (1956).

54) MANN, H.H.and T. W. Barnes: The competition between barley and certain weeds under controlled conditions. I-V. Ann. Appl. Biol. 32 (1): 15-22 (1945), 34 (2): 252-266 (1947), 36 (2): 275-281 (1949), 37 (2): 139-148 (1950), 39 (1): 111-119 (1952).

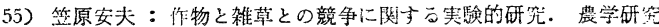
18 (4): 199-236, 49 (1): 9-47 (1961).

56) Molisch, H.: Der Einfluss einer Pfanze auf die Andere, Allelopathie. Jena (1937).

57) Osvald, H.: Root exudates and seed germination. Ann. Roy. Agr. Coll. Sweden 16: 789-796 (1949).

58) BonNer, J.: The role of toxic substance in the interrelations of higher plants. Bot. Rev. 16: 51-6j (1950).

59) Grümmer, G.: Die gegenseitige Beeinflussung höherer Phanzen-Allelopathie. Jena (1955).

60) Martin, P.and B.Rademacher: Studies on the mutual influences of weeds and crops. The Biology of Weeds: 143-152 (1960).

61) Whyte, R. O. ed.: The Control of Weeds. Aberystwyth (1940).

62) MIYawakr, A.: Pflanzensoziologische Lntersuchungenüber Reisfeldvegetation auf den Japanischen Inseln mitvergleichender Betrachtung Mitileleuropas. Vegetatio 9: 346-40: (1960).

63）沼田真：植物の生態研跳法・微生物の生態：1-19 (1961). 
64) 渻水正元：土㙋反応と植物の生育. 日草地研会誌 5 (2) : 78-80 (1960).

65) Numata, M.: Statistical methodology in plant ecology. Bull. Intern. Stat. Inst. 38 (Part 4): 547-553 (1961).

66) 荒井正雄・川島良一：水稻栽培に括ける雑草害の生態的研究 $I$, II. 日作紀 25 (2):115-119 (1956).

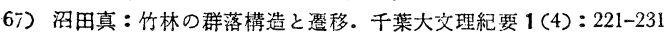
(1955).

68）川延䔆造：トラクターの利用を前提とした畑作柴体系の確立に関 寸る研究 (I). 東大䔶場研究報告第 1 号 : 1-163 (1962).

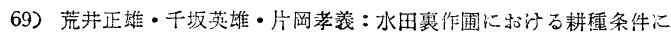
よる雑草群落の変化，第 3 報. 日作紀 27 (3):387-390 (1959)。

70) 沼田真・小村登志于・大木苤・林一六：逶移からみた埋土種子集 団の解析. 日本植物学会第26回大会講演要旨: 17 (1961).

71) 沼田真: 生物集団の恋遷に関する二三の問題一とくに植物群落の 镸移と生活型の進化沉ついて。生物進化 1:5-14 (1953).

72) 沼田真：植物の生態的な進化. 遗伝 12 (10): 54-56 (1958).

73) 沼田真：植物の適応と進化一生態学の立場から。ダーウイン進化 論百年鼣念論集 : $171-179$ (1960). 